\section{Sex Chromosome Abnormality in a Patient with Transsexualism}

\author{
SHEELAH JAMES, A. ORWIN, \\ D. WYNNE DAVIES
}

British Medical fournal, 1972, 3, 29

Transsexualism, defined as the wish to change anatomical sex (Benjamin, 1954), is a psychosexual disorder usually not associated with physical abnormalities (Randell, 1970) or abnormality of the sex chromosomes (Money, 1963). In males with Klinefelter's syndrome, where there is an additional $\mathrm{X}$ chromosome, cases have been described with coincidental transsexualism (Money, 1963) and transvestism (Money and Pollitt, 1964). This may be fortuitious, though study of the psychological effect of chromosomal anomalies has been scanty.

We describe here a case of transsexualism in a woman with an abnormality of the sex chromosomes-namely, $\mathrm{XO} / \mathrm{XX}$ mosaicism.

\section{Case Report}

A 21-year-old woman was referred by her general practitioner for treatment of lesbianism. She had had a stable relationship with another woman of the same age for five years. Her parents disclosed in confidence that she was adopted and they knew nothing of her family.

An only child, she had apparentiy been happy with no neurotic traits, but from the age of 8 she had proclaimed her wish to be male and insisted on dressing as a boy. She had been an average scholar at a private school, leaving at the age of 15 . She had many jobs, preferring masculine work such as in a garage or driving, and often passed as a man among her workmates. Embarrassment over her transsexualism was the usual cause for leaving.

Menarche was at 16 years and menstruation, which had been regular, was resented because it was a reminder of her femininity. She began to feel protective towards girls and developed emotional relationships with them and some sexual play occurred in which she always took the active role, her girl-friends being heterosexual and not homosexual in their previous activities. The patient had never been sexually aroused by males, looking on them as equals and viewing sex with them as homosexual behaviour.

She was first referred for a psychiatric opinion at the age of 16 after starting work as a nursing auxiliary when a female nurse made a suicide attempt because of her feelings for the patient. The psychiatrist considered her transsexualism as merely a manifestation of a lesbian phase and that no further action was required. She had a transient optic neuritis shortly after this but needed no further medical care until the present referral, for what was superficially a homosexual problem.

Psychiatric Examination.-She was dressed in drab trousers, pullover, and heavy shoes. Her hair was straight and her facial appearance was in keeping with the masculine dress and manner that she adopted. She sat with her legs apart, smoked heavily, and was noticed to play a masculine role in the presence of other females-for example, opening doors for them. She described herself as a "male mind in a female body." She appre-

Regional Behaviour Research Unit, Hollymoor Clinic Hollymoor, Hospital, Birmingham 31

SHEELAH JAMES, M.B., D.P.M., Research Assistant

A. ORWIN, L.R.C.P., D.P.M., Consultant in Charge

D. WYNNE DAVIES, M.B., B.S., M.R.C.P., Consultant Physician ciated that she could not become a normal man and desired no more than social acceptance, but since adolescence she had collected newspaper cuttings about sex-change operations. She asked about androgen therapy and a bilateral mastectomy but was not insistent, realistically limiting her goal to society's tolerance of her male role. She was of average intelligence (I.Q. 106 W.A.I.S. full scale) and displayed no evidence of psychosis. She admitted to anxiety, tension headache, and episodic depression related to frustration at not being accepted as a man.

Physical Examination.-She was thin, pale, was 5 ft 4 in (153 cm) tall, and weighed 7 st $11 \mathrm{lb}(49.4 \mathrm{~kg})$. Secondary sex characteristics were normal. A high arched palate, incurved little fingers, relatively short halluces, and an exostosis on the left wrist were the only abnormal findings.

Laboratory Investigations.- $\mathrm{Hb} \quad 11.6 \mathrm{~g} / 100 \mathrm{ml}$, W.B.C. $6,800 / \mathrm{mm}^{3}$; serum urea $19 \mathrm{mg} / 100 \mathrm{ml}$; serum total protein 7.8 $\mathrm{g} / 100 \mathrm{ml}$; serum calcium $10 \cdot 2 \mathrm{mg} / 100 \mathrm{ml}$; serum inorganic phosphate $3.0 \mathrm{mg} / 100 \mathrm{ml}$; blood W.R. and V.D.R.L. tests negative; routine urine analysis normal. Chest $x$-ray examination showed nothing abnormal apart from a narrow transverse cardiac diameter. Skull $x$-ray appearances were normal. Prominent vascular markings in the frontal zone were regarded as a normal variant. On E.E.G. no paroxysmal discharge or persistent focal abnormalities were recorded but there was a moderate excess of slow and sharp waves in the posterior half of both hemispheres. Buccal smear showed $12 \%$ of cells chromatin positive. Blood chromosome analysis confirmed XO/XX mosaicism, $40 \%$ of cells showing $45 \mathrm{XO}$ chromosome complement, the remainder a normal female karyotype (46XX). Amino-acid chromatography, nil abnormal. Twenty-fourhour urine: amino-acids $465 \mathrm{mg} \alpha$-amino-acids (normal 175530); and creatinine $810 \mathrm{mg}$; F.S.H. gonadotrophin by radioimmunoassay $12.0 \mathrm{IU} / 24 \mathrm{hr}$ (equivalent to a high result by bioassay).

\section{Comment}

The physical normality of transsexuals was commented on by Randell (1970) and Pauly (1965), but isolated cases of gonadal dysgenesis associated with transsexualism or transvestism have been described by Baker and Stoller (1968). The diagnosis of transsexualism was made here from the history in a woman with apparently normal sexual anatomy and without evidence of psychosis. The combination of $\mathrm{XO} / \mathrm{XX}$ mosaicism and transsexualism in this patient is of special interest for we are not aware of a similar case, though $\mathrm{XO} / \mathrm{XX}$ mosaicism associated with psychosis, and E.E.G. abnormalities (Mellbin, 1966), and anorexia nervosa (Forssman et al., 1970) has been reported. Our findings could be fortuitious because females with $\mathrm{XO}$ or $\mathrm{XO} / \mathrm{XX}$ karyotype have been found to have entirely feminine self-concepts and to be heterosexual even when there was amenorrhoea and absence of secondary sex characteristics (Money, 1963).

We are grateful to Dr. R. A. Carter, consultant pathologist, and Dr. R. K. Turner, principal psychologist, Hollymoor Hospital, for their help. We would also like to thank Dr. T. C. Williams, consultant pathologist, Marston Green Maternity Hospital, Birmingham, for the blood chromosome analysis.

\section{References}

Baker, H. J., and Stoller, R. J. (1968). American fournal of Psychiatry, $124,1653$.

Benjamin, H. (1954). American fournal of Psychotherapy, 8, 219.

Forssman, H., Mellbin, G., and Walinder, J. (1970). British fournal of Psychiatry, 116, 221.

Mellbin, G. (1966). British fournal of Psychiatry, 112, 145.

Money, J. (1963). American fournal of Psychiatry, 119, 820.

Money, J., and Pollitt, E. (1964). Archives of General Psychiatry, 11, 589.

Randell, J. (1970). British Fournal of Hospital Medicine, 3, 211. 